\title{
SEASONAL DYNAMICS OF BENTHIC COMMUNITIES IN A SHALLOW SUBLITTORAL SITE OF LAGUNA ESTUARINE SYSTEM (SOUTH, BRAZIL)
}

\author{
MEURER, A.Z. \& NETTO,S.A. \\ Laboratório de Ciências Marinhas, Universidade do Sul de Santa Catarina \\ Av Colombo Sales 84, Laguna, SC, 88790-000, Brasil. \\ E-mail: sergio.netto@unisul.br
}

\begin{abstract}
Meurer, A.Z. \& Netto,S.A. 2007. Seasonal dynamics of benthic communities in a shallow sublittoral site of Laguna Estuarine System (South, Brazil). Braz. J. Aquat. Sci. Technol. 11(2):53-62. ISSN 1808-7035. The seasonal variability of the benthic community in a shallow sublittoral site was analyzed at the Laguna Estuarine System, a chocked lagoon in South Brazil. Seasonal replicate samples for the microphytobenthos, meiofauna and macrofauna were undertaken from October 2003 to October 2004. The analysis of the different component of the benthos permitted to show a clear temporal asynchrony in the microphytobenthos biomass, meiofauna and macrofauna univariate measures increase and decline. Sediment chlorophyll $a$ and phaeopigments followed a similar seasonal trend, with low biomass in the winter, higher in the summer and intermediate values in spring and autumn. The benthic fauna components of the Laguna Estuarine System also showed a clear seasonal oscillation, but with an opposite pattern of variation. Whilst the number of species and abundance of the macrofauna were significantly higher in the spring and summer, for the meiofauna, both the number of taxa and abundances were significantly higher during the winter and autumn. The results of this study suggested that the divergent seasonal variations of the meiofauna and macrofauna may be linked to their different life strategies, and that biological interactions between meiofauna and macrofauna may also play a significant role in structuring these communites.
\end{abstract}

Keywords: seasonal variability, microphytobenthos, meiofauna, macrofauna, Laguna Estuarine System, Brazil.

\section{INTRODUCTION}

Benthic communities play a critical role in the functioning of estuaries. Microphytobenthos and benthic consumers are essential components of coastal ecosystems (Maclntyre et al., 1996) influencing sediment biogeochemistry via uptake and release of nutrients (Rizzo et al., 1992), and sediment erosion via their production of exopolymers (Grant et al., 1986). Microphytobenthos, more nutritious and labile than other vascular plants, are a major source of nutrition that fuels secondary production (Buffan-Dubau \& Carman, 2000; Sullivan \& Moncreiff, 1990). The invertebrate benthic species - meiofauna and macrofauna - provide key linkages between primary producers and higher trophic levels in estuarine food chains (Gee, 1989; Moens \& Vincx, 1996).

Throughout the world, estuaries are among the most modified and threatened of aquatic environments. Almost all of them have been affected by human beings in some way. The degree of degradation varies, but in some estuaries, the shape, hydrology, and functioning of the system have been completely altered. Relatively few remain in anywhere near a natural state (Blaber et al., 2000). Benthic invertebrates are extensively used as indicators of estuarine environmental status and trends because numerous studies have demonstrated that benthos respond predictably to many kinds of natural and antropic disturbances (e.g. Coull \& Chandler, 1992; Hall, 1994; Thrush \& Dayton, 2002). Contaminants often accumulate in sediments and, therefore, the relative immobility is advantageous in environmental assessments because, unlike most pelagic fauna, benthic assembles reflect local environmental conditions. However, a major methodological limitation for determining the estuary environmental status is the lack of knowledge about temporal variability of benthic fauna, which makes it difficult to distinguish between man-made and natural variability (Morrisey et al., 1992).

Meiobenthos and macrobenthos, apart from the difference in size, have a series of distinctive ecological and evolutionary characteristics which suggest different mechanisms for diversity maintenance (Warwick, 1989; Warwick et al., 2006). The dynamics of each component of the benthos may also differ depending on the environmental conditions and trophic state (Koop \& Griffiths, 1982; Danovaro et al., 1995). Surprisingly, data on simultaneous seasonal comparisons between macrofauna and meiofauna in estuaries or coastal lagoons are rare (Montagna \& Kalke, 1992; Bolam et al., 2006; Fonseca \& Netto, 2006). The aim of this study is to describe and to compare the seasonal variability of the benthic communities - microphytobenthos, meiofauna, macrofauna - in a sublittoral shallow site of 
the Laguna Estuarine System, a coastal lagoon in south Brazil.

\section{MATERIAL AND METHODS}

\section{Study area}

The Laguna Estuarine System, located at the State of Santa Catarina, South coast of Brazil $\left(28^{\circ} 12^{\prime} S\right.$ $-48^{\circ} 38^{\prime}$ E; Fig. 1), is a chocked lagoon with an area of $184 \mathrm{~km}^{2}$. The estuarine system, bounded by salt marshes, is composed by three main lagoons orientated parallel to the shore line and faintly connected among them and with the adjacent ocean. The Laguna Estuarine System is separated from the ocean by a sand barrier with large dune fields at the north. Southwards, most of the sand dunes were destroyed by human occupation. The western portion of the estuarine system is characterized by a high land formation, the Serra do Tabuleiro. Although Laguna Estuarine System experience tides that co-oscillate with tides in South Brazil coastal ocean (mean of 0.47 m; Defant, 1961), the narrow entrance channel serves as a dynamic filter which largely eliminates tidal currents and water-level fluctuations inside the lagoon. Mean depth of the lagoons is around $2 \mathrm{~m}$, and therefore, wind could play a significant role in water circulation (Eichler et al., 2006; Fonseca \& Netto, 2006). The NE winds are the most frequent, but during the winter S-SE winds may be equally common. Mean air temperatures in the winter is around $13^{\circ} \mathrm{C}$ and in the summer around $22^{\circ} \mathrm{C}$; total annual rainfall mean is $1,260 \mathrm{~mm}$ with no marked differences along the year (EPAGRI, 2006). There are little studies of the Laguna estuarine System. Data on the composition and distribution of the meiofauna and macrofauna from sublittoral areas along the lagoon are found in Fonseca and Netto (2006).

\section{Sampling and samples processing}

A temporal nested sampling scheme (Underwood, 1997) was adopted in this study. Monthly samplings taken in randomly and independently dates were used as replicates of each season. The samplings were carried out in a shallow sublittoral site (ca. $1 \mathrm{~m}$ depth; $28^{\circ} 24^{\prime} 34^{\prime \prime} S$ - $48^{\circ} 52^{\prime} 45^{\prime \prime} E$ ) covering summer, autumn, winter and spring from October 2003 to October 2004 (Fig. 1). Four samples were undertaken for each component of the benthic community microphytobenthos $(2 \mathrm{~cm}$ diameter core pushed to a depth of $1 \mathrm{~cm})$, meiofauna $(2 \mathrm{~cm}$ diameter $x 10 \mathrm{~cm})$ and macrofauna $(15 \mathrm{~cm}$ diameter $x 10 \mathrm{~cm}$ ). Additionally, four sediment samples for organic matter and grain size determination were taken with a PVC core of $10 \mathrm{~cm}$ in diameter pushed to a $5 \mathrm{~cm}$ depth. Depth, water salinity and temperature values were recorded with an YSI 600 multiparameter system. Microphytobenthos samples were stored in dark plastic pots and frozen $\left(-12^{\circ} \mathrm{C}\right)$, and faunal samples fixed in $10 \%$ formalin before processing.

The sediment chlorophyll $a$ and phaeopigments biomass were extracted with $90 \% \mathrm{v} / \mathrm{v}$ acetone and analysed according Strikland \& Parsons (1972). Chlorophyll $a$ and phaeopigments concentration were estimated using Lorenzen's (1967) equation. Meiofauna samples were sieved through a $63 \mu \mathrm{m}$ mesh and extracted by flotation with Ludox TM 50 (specific gravity of 1.15). Samples were then evaporated to anhydrous glycerol and permanent slides made (Somerfield \& Warwick, 1996). Fixed macrofaunal samples were sieved through a $0.5 \mathrm{~mm}$ mesh and preserved in $70 \%$ alcohol. All invertebrates were identified to the lowest possible taxonomic level and counted. The total sediment organic content was determined by combustion at $550^{\circ} \mathrm{C}$ for 60 minutes and granulometry was done by sieve and pipette methods (Kettler et al., 2001).

\section{Data analyses}

Data were analyzed using univariate and multivariate statistical techniques. Data from monthly samplings were nested into seasons. The univariate descriptors used for the fauna were number of species and total density. Test for differences in the environmental variables - total organic content, percentage of sand

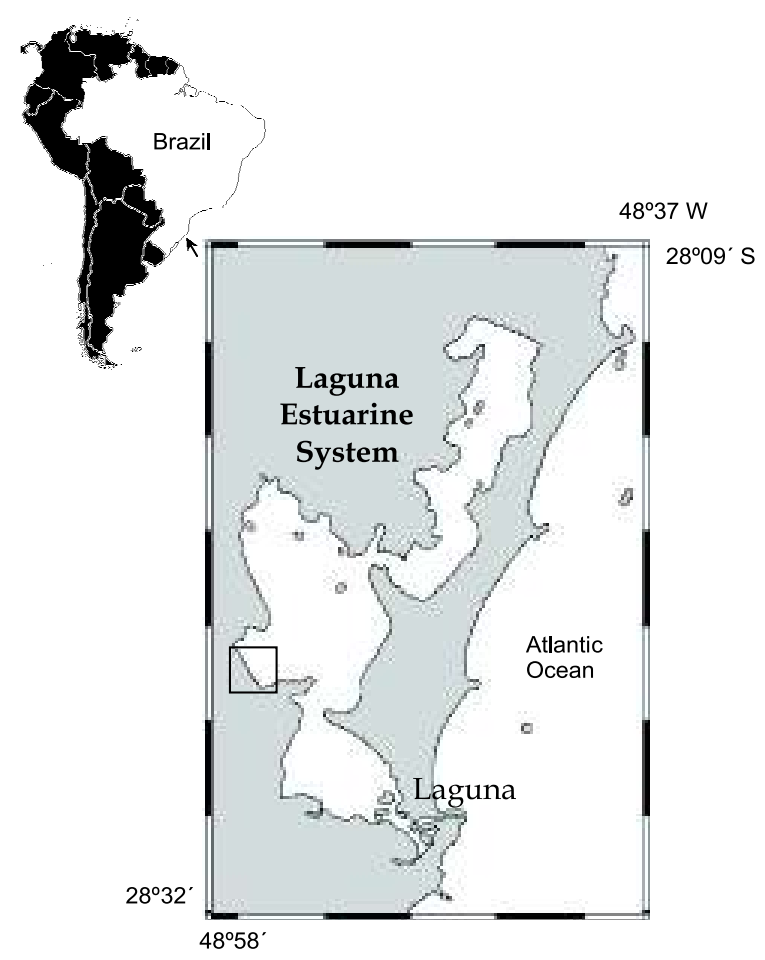

Figure 1 - Location of the sampling site at Laguna Estuarine System, South Brazil. 
and silt, mean grain size, sorting, salinity and temperature values - macrofauna, meiofauna and nematodes number of species (or taxa) and density, and microphytobenthos (chlorophyll $a$ and phaeopigments biomass) between periods (spring, summer, autumn and winter) were carried out by 1-way ANOVA (Sokal \& Rohlf, 1997). In order to test the assumption of homogeneity of variances, Cochran's C tests were applied and where necessary, data were log $(\mathrm{x}+1)$ transformed. The post-hoc HSD-Tukey tests were applied when differences were significant $(p<0.05$; Sokal \& Rohlf, 1997). Ranked lower triangular similarity matrices derived from macrofauna, meiofauna and nematode abundance were constructed using the BrayCurtis similarity measure on $\log (x+1)$ transformed data. Ordinations were conducted using non-metric multidimensional scaling (MDS). Formal significance tests for differences in the multivariate structure of benthic communities between periods were performed using the 1-way ANOSIM permutation test (Clarke \& Green, 1998). The relationships between the environmental variables and biological data were analyzed using a correlation based principal component analysis (PCA). Also, Pearson product-moment correlations for all abiotic and biotic univariate data were performed.

\section{RESULTS}

\section{Environmental variables}

Mean values and the results of the ANOVA test for differences in the environmental variables are shown on Table 1. Water temperature was significantly higher on summer, while salinity was significantly higher in autumn and winter (Table 1). Sediments were characterized by medium silt, moderately sorted, with total organic content values between $4 \%$ and $12 \%$. The fine percentages (silt and clay) were significantly higher in spring (mean of $94.1 \%$ ) than in the other seasons.

Table 1 - Mean, standard deviation (in parenthesis) and the results of the 1-way ANOVA tests evaluating changes of the environmental variables among sampling periods in a shallow site of the Laguna Estuarine System (S Brazil). Comparisons among periods determined by the Tukey's post hoc test. Su - summer; $\mathrm{S}$ - spring; W - winter; A autumn; ns - no significant differences

\begin{tabular}{lccccc}
\hline \hline & \multicolumn{5}{c}{ Period } \\
\cline { 2 - 5 } & Spring & Summer & Autumn & Winter & Comparison \\
\hline Temperature $\left({ }^{\circ} \mathrm{C}\right)$ & $25(4.5)$ & $25.5(1.5)$ & $22(4.5)$ & $20.5(2.5)$ & Su>W \\
Salinity & $13(3)$ & $12(2)$ & $19(4)$ & $19(4)$ & W,A $>\mathrm{Su}, \mathrm{S}$ \\
Mean grain size (mm) & $0.02(0.002)$ & $0.02(0.002)$ & $0.02(0.002)$ & $0.02(0.002)$ & $\mathrm{ns}$ \\
Sorting & $0.9(0.15)$ & $1.1(0.16)$ & $1.0(0.22)$ & $1.0(0.06)$ & $\mathrm{ns}$ \\
Sand (\%) & $5.7(2.5)$ & $10.0(3.3)$ & $9.2(1.9)$ & $8.4(2.2)$ & $\mathrm{S}<\mathrm{Su}, \mathrm{A}, \mathrm{W}$ \\
Silt-clay content (\%) & $94.1(3.5)$ & $90.0(3.3)$ & $90.8(1.9)$ & $91.6(3.2)$ & $\mathrm{S}>\mathrm{Su}, \mathrm{A}, \mathrm{W}$ \\
Organic content (\%) & $7.8(1.3)$ & $6.8(2.8)$ & $8.0(2.8)$ & $8.5(1.5)$ & $\mathrm{ns}$ \\
\hline
\end{tabular}

Total sediment organic content, with a mean around $8 \%$, did not vary significantly among seasons (Table 1 ). Ordination by a correlation-based principal component analysis of the average environmental data (Fig. 2) showed a distinction between spring-summer and autumn-winter periods (particularly on the component 2). Components 1 and 2 were responsible for 63.3 of the total variability (PC1 $41.2 \%$; PC2 22.1\%). Spring and summer periods were associated to temperature and total organic content, whilst autumn-winter months were related to salinity and clay values. Spring samples were also correlated with total organic content and summer with mean grain size.

\section{Microphytobentos}

Total microphytobenthos biomass varied significantly along the year, with values ranging from $0.11 \mathrm{mg} \cdot \mathrm{m}^{-3}$, at the end of winter, to $57,350 \mathrm{mg} \cdot \mathrm{m}^{-3}$ in summer. Chlorophyll a biomass in the surface sediment ranged between 0.007 and $24.489 \mathrm{mg} \cdot \mathrm{m}^{-3}$ and was significantly lower in the winter (Fig. 3). Differences in chlorophyll a biomass among the other periods were not significant $(p<0.05)$. Phaeopigment biomass, ranging from 0.1 to $33,443 \mathrm{mg} \cdot \mathrm{m}^{-3}$, was significantly higher in the summer and autumn and lower in the winter and spring (Fig. 3). Mean values of chlorophyll a biomass $\left(9,523 \mathrm{mg} \cdot \mathrm{m}^{-3}\right)$ were lower than phaeopigments $(16,366$ $\left.\mathrm{mg} \cdot \mathrm{m}^{-3}\right)$, but the differences were not significant $(p<0.05)$.

\section{Benthic fauna}

Univariate descriptors

A total of 15 macrofaunal species were recorded in this study, with densities ranging between 176 and 49.235 inds. $\mathrm{m}^{2}$. The polychaetes Heteromastus similis ( $45 \%$ of the total macrofauna collected) the unidentified species of oligochaetes ( $18 \%$ of the total fauna) and

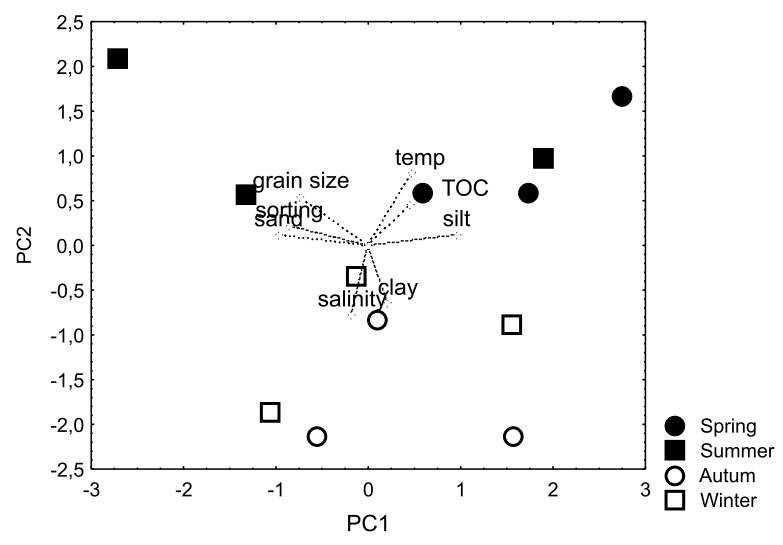

Figure 2 - Ordination by a correlation-based principal component analysis of the average environmental data. 


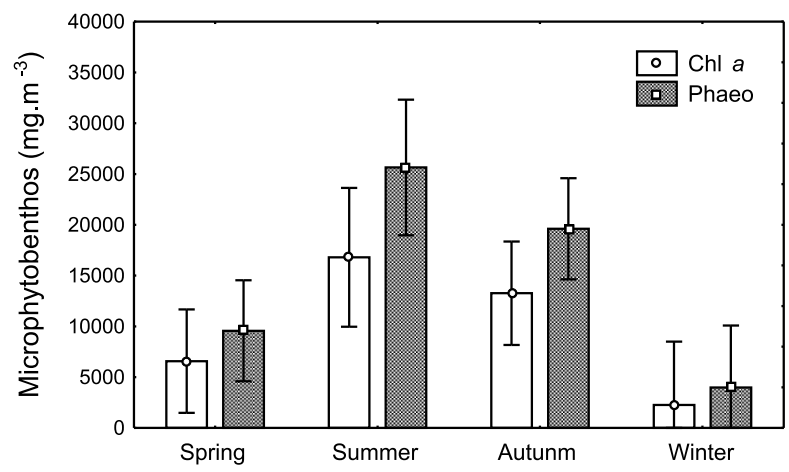

Figure 3 - Sediment chlorophyll a and phaeopigment concentrations $($ mean $\pm \mathrm{SE})$.

ostracods ( $15 \%$ of the total macrofauna) were the most abundant species. Apart from $\mathrm{H}$. similis, the polychaetes Laeoneris acuta, Nephtys fluviatilis, and the gastropod Heleobia australis were the most frequent species along the sampling period, occurring in more than $70 \%$ of the samples.

The number of species and the total density of the macrofauna were significantly higher in the spring and summer, and lower in the winter and autumn (Fig. 4). $H$. similis was the only macrobenthic species that did not varied significantly among sampling periods. Densities of all other macrobenthic taxa showed the same tendency of univariate descriptors- significant higher values in the spring and summer, and lower in the winter and autumn.

The meiofauna was composed of 8 higher taxa and numerically dominated by nematodes (more than $80 \%$ of the total meiofauna collected). Copepods and temporary meiofauna (polychaetes and oligochaetes) were also abundant groups, accounting for $9 \%$ and $2 \%$ of the total meiofauna respectively. The density of the meiofauna, strongly influenced by the nematodes, ranged between 165 and 4,550 inds. $10 \mathrm{~cm}^{-2}$.

A total of 40 nematode genera was recorded in this study. The most abundant genera were Leptolaimus, Terchellingia, Parodontophora, Theristus and Sabatieria. Together, these genera represented $62 \%$ of the total nematodes and occurred in more than $80 \%$ of the samples. Theristus and Sabatieria were recorded in all meiofauna samples. The results of the ANOVA tests showed that the seasonal oscillations of both the meiofauna and the nematode descriptors were the opposite from those exhibited by the macrofauna. The number of the meiofauna higher taxa, genera of nematodes and total density of meiofauna and nematodes were significantly higher in autumn and winter (Fig. 4).

The relative abundance of the permanent and temporary meiofauna organisms along the sampling period is shown on Figure 5. It can be observed that temporary meiofauna followed the same seasonal trend of the macrofauna, indicating recruitment episodes. Temporary meiofauna abundances were significantly higher in the summer and spring (Fig. 5).

Multivariate community structure

The MDS ordination derived from the macrofauna, meiofauna and nematodes transformed data are shown in Figure 6. All the components of benthic fauna showed a clear temporal oscillation, though for nematodes the seasonal variation was more pronounced (Fig. 6). The ANOSIM tests confirmed the significance of the differences $(p<0.05)$, but pairwise comparisons between seasons showed that, for the meiofauna data, spring and summer did not varied significantly $(p>0.05)$. For macrofauna and nematode data, the ANOSIM pairwise comparisons showed the multivariate community structure differed significantly among all seasons.

Benthic components and environmental variables interactions

The relationships between abiotic and biological data were investigated using a standard product-moment correlation analysis. Meiofauna richness was negatively correlated with macrofauna abundance $(-0.45)$ while meiofauna density was positively correlated with salinity (0.5). For nematodes, significant correlations were detected only for the number of genus, positively related with salinity $(0.5)$ and negatively correlated with temperature (-0.4). Both abundance and richness of the macrofauna were negatively correlated with the phaeopigment biomass ( 0.5 and 0.6 respectively).

PCA derived from benthic fauna data, microphytobenthos biomass, sediment data, salinity and temperature values showed a clear distinction between sampling seasons (Fig. 7). Components 1 and 2 were responsible for $51.1 \%$ of the total variability ( $P C 1$ - 28.5; PC 2 - 22.6). The projection of the variables on components 1 and 2 showed that winter and autumn samples were related to meiofauna and nematodes descriptors, as well as to the salinity and phaeopigment biomass. Summer and spring samples were mainly associated to macrofauna number of taxa and abundances, temperature and total organic content.

\section{DISCUSSION}

The benthic communities at the study site exhibited a marked seasonal variability. However, the analysis of the different component of the benthos permitted to show a clear temporal asynchrony in the microphytobenthos biomass, meiofauna - both temporary and permanent - and macrofauna univariate measures. Apart from the water temperature and salinity, 

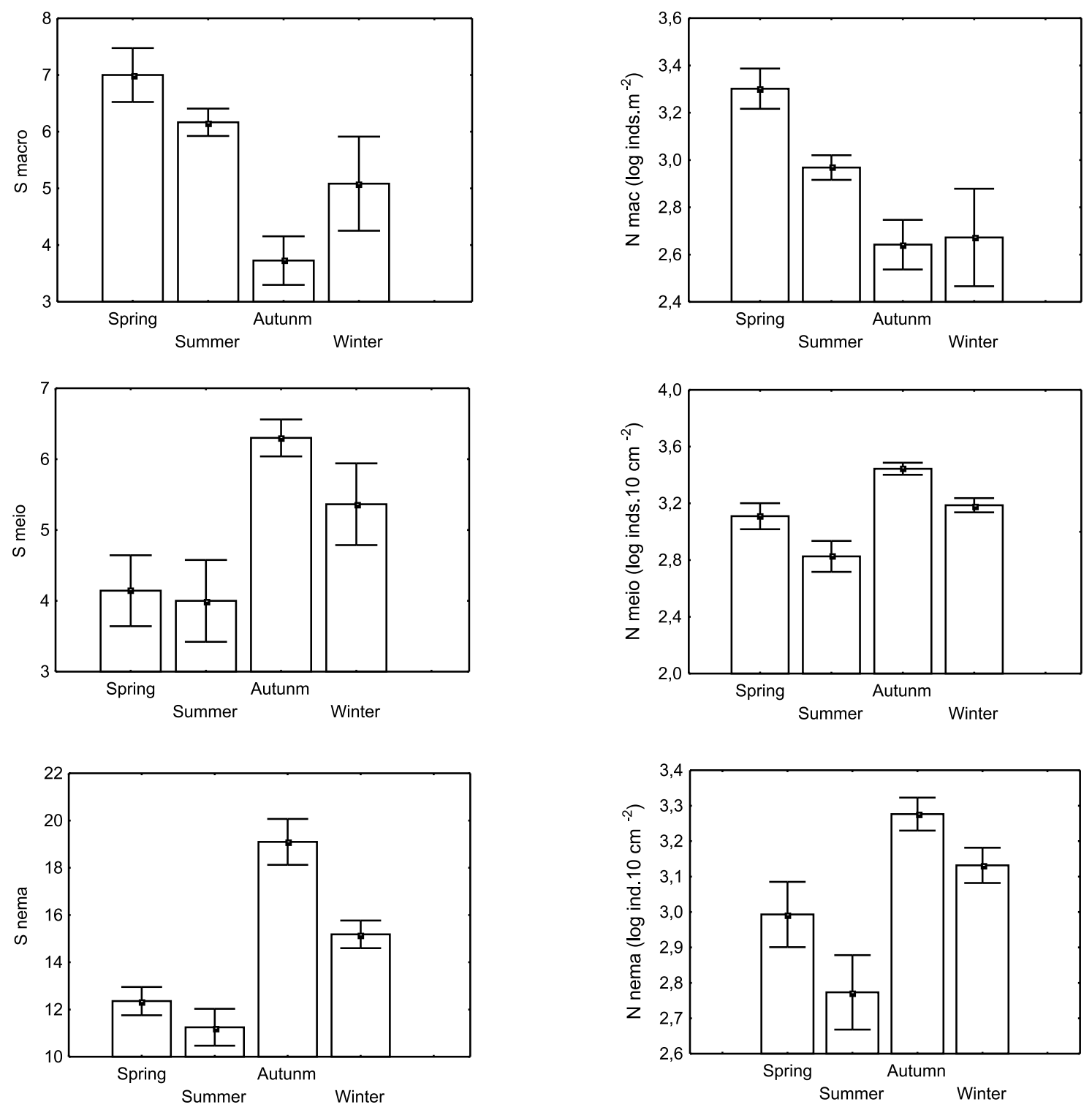

Figure 4 - Univariate measures (mean $\pm \mathrm{SE}$ ) of macrofauna ( $\mathrm{S}$ mac -number of species; $\mathrm{N}$ mac -density), meiofauna ( $\mathrm{S}$ meio - number of higher taxa; $\mathrm{N}$ meio - density) and nematodes ( $\mathrm{S}$ nema -number of genera; $\mathrm{N}$ nema - density).

none of the sediment parameters changes were related to the seasonal variability of the fauna.

The most important variables controlling oscillations of sublittoral benthic organisms on an estuarine scale are salinity and sediment characteristics, which are in turn determined largely by the hydrodynamic conditions of the estuary (Attrill \& Rundle, 2002; Bemvenuti \& Netto, 1998; Lana, 1986; Lana et al., 1997; Warwick et al., 1991). Water circulation in chocked lagoons, such as Laguna Estuarine System, is mainly wind-driven (Kjerfve, 1988). Local micro-tidal regimes together with the lack of marked rainfall differences over the year (EPAGRI, 2006) determine that the wind exerted a key role in the hydrodynamic conditions of the Laguna Estuarine
System. During summer and spring months, when the wind blows mainly from NE, the lagoon water masses are pushed towards the southern margins which results in a decreased salinity. In contrast, during winter and autumn, periods of strong S-SE winds favor marine water intrusion into the lagoon resulting in higher salinity values. Although, short-term oscillations are also frequent, these results at within-site scale are similar to those previously observed for the region by Eichler et al. (2006) and Fonseca \& Netto (2006).

Sediment properties at the study site were relatively stable along the study. Mean grain size did not vary significantly over the seasons and only fine percentages increased in spring. Apart from oscillations due to river discharges, Fonseca \& Netto (2006) 


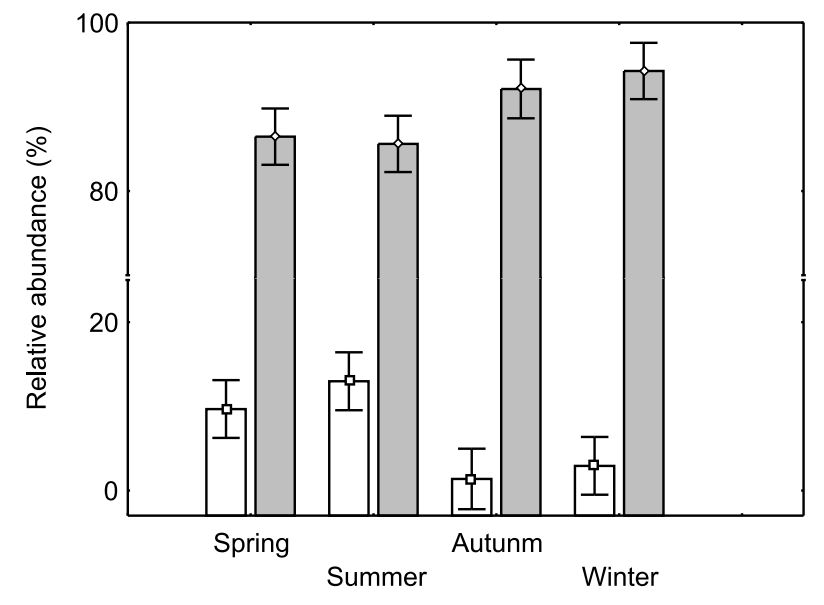

Figure 5 - Relative abundance (mean \pm SE) of temporary (white bars) and permanent meiofauna (grey bars).

observed that sediment transport from sand dunes, mainly during summer and spring, may increase sand percentages in the east bottoms of the Laguna Estuarine System. The study site, however, was located in west margin of the lagoon and probably too far from the dune fields to suffer this sort of influence. As sublittoral areas of coastal lagoons are generally shallow, they easy remobilized by wind waves (Nichols \& Boon, 1994). Rosa and Bemvenuti (2006) showed that at Patos Lagoon (South, Brazil), the increase of wind intensity changes the local hydrodynamics favoring the resuspension, transport and deposition of sediment. The study site is exposed to the NE winds, which are strongest during spring (EPAGRI, 2006). Thus it is possible that the increase in fine sediments during the spring could a result of the wind-driven sediment resuspension and deposition on the lagoons floor, as also suggested by Shideler (1984).

Sediment chlorophyll $a$ and phaeopigments followed a similar seasonal trend, with low biomass in the winter, higher in the summer and intermediate in spring and autumn. Pronounced seasonality is a typical feature of microphytobenthic communities in estuarine areas and several studies have shown that seasonal variations are mainly driven by temperature and irradiance (Admiraal \& Peletier, 1980; Sundbaeckm et al., 2000). At shallow sublittoral bottoms, benthic microalgae usually show biomass peaks similar to the water column due to an increase in sediment surface temperature and to the deposition of the pelagic algae. At the study site, values phaeopigment biomass, composed of photosynthetic pigment degradation products, was generally higher than chlorophyll $a$. Although the benthic fauna may have a significant contribution to the degradation of chlorophyll $a$ into phaeopigments, as showed by correlation and the principal component analysis, this result probably reflects mainly the local predominant sedimentation process which the area is subjected to, and where the chlorophyll a decomposition rates are high (Pinckney \& Zingmark, 1993).

The studied benthic fauna components of the Laguna Estuarine System showed a clear seasonal variation, though with an opposite pattern of variation. Whilst the number of species and abundance of the macrofauna were significantly higher in the spring and summer, for the meiofauna, both the number of taxa and abundances were significantly higher during the winter and autumn. Moreover, values of correlations between benthic fauna and the environmental variables (meiofauna and nematodes positively correlated with salinity and macrofauna positively correlated with temperature) were similar to those exhibited between the univariate descriptors of the two faunal components (number of nematode genus negatively correlated with macrofauna density). Therefore, these results probably indicated that the divergent seasonal variations of the meiofauna and macrofauna may be linked to their different life strategies, and that possible biological interactions between meiofauna and macrofauna may also play a significant role in structuring these associations.

It is already known that meiofauna and macrofauna have different mechanisms for diversity maintenance (Warwick, 1984). Although scanty, the studies that simultaneously compared seasonal variability between estuarine meiofauna and macrofauna did show different trends in variation (Fonseca \& Netto, 2006; Montagna \& Kalke, 1992). In addition to be conservatively separated on the basis of size, meiofauna and macrofauna each have a series of distinctive biological traits resulted from evolutionary adaptations to the spatial and temporal structure of the marine environment, rather than ecological constraints imposed by the physical nature of particular habitats (Warwick et al., 2006). Reproduction, growth and feeding strategies differ between meiofauna and macrofauna. Moreover, the response of the meiobenthos to the constant and unpredictable disturbances of which shallow sedimentary bottoms are subjected to is not always the same as that those exhibited by the macrobenthos (Austen \& Widdcombe, 2006; Gallucci \& Netto, 2004).

Aside from the different life strategies, biological interactions between meiofauna and macrofauna could possible contribute to the observed opposite seasonal variation showed by the benthic faunal components. Warwick (1989) suggested that the reason why it should have been necessary for larger animals (macrofauna) to have evolved a planktonic larva was to avoid competition with and predation by the permanent meiobenthos, which constitute a highly efficient 


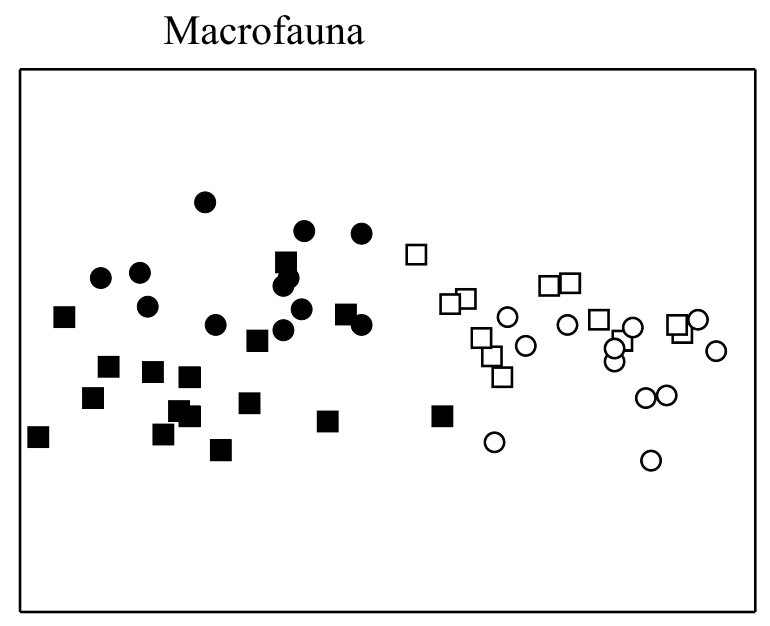

Nematoda

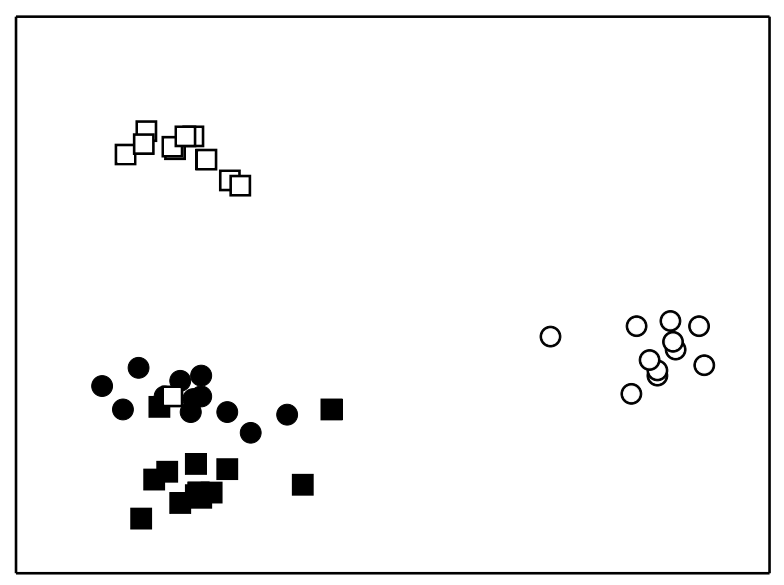

consumer unit. At studied site, the increase of reproductive activity of macrofaunal species during spring and summer, as showed by the highest densities of temporary meiofauna, coincided with the lower peak of the meiofauna densities. Moreover, the highest peak of the meiofauna, during autumn and winter months, corresponded to the decrease of the macrobenthos recruits. Indeed, Danovaro et al. (1995) showed that selective predation operated by meiofauna on the dominant polychaete families of the temporary meiofauna may structure macrofaunal communities both altering density and acting selectively on a few families of macrofaunal juveniles.

The results of experimental studies that have considered overall effects of macrofauna originating from processes such as predation, bioturbation and competition for food also indicate effects on meiobenthos (Ólafsson, 2003). For example, Alongi \& Tenore (1985) showed Capitella capitata-meiofauna interactions led to reduced abundances of all of the nematode species due to food competition. Tita et al. (2000) demonstrated that
Meiofauna

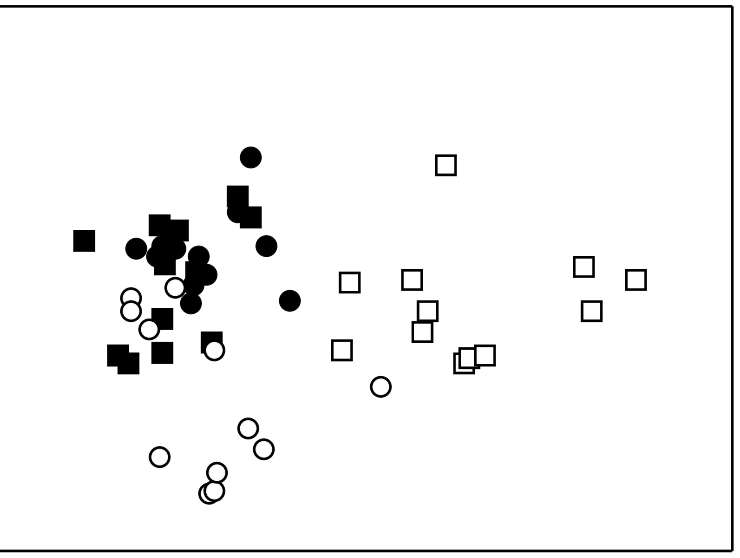

Figure 6 - MDS ordination for transformed macrofauna, meiofauna and nematode abundances. - summer; $\bullet$ spring; $\square$ - winter ; $\bigcirc$-autumn.

high densities of a species of nereididae polychaete affected meiofauna both by predation and disturbance of the intricate nematodes system of tubes in the sediment, reducing their feeding opportunities.

\section{CONCLUSIONS}

The meiofauna and macrofauna communities from a sublittoral muddy site at Laguna Estuarine System, South Brazil, showed a marked seasonal variability. Richness and population densities of macrobenthic invertebrates were significantly higher during spring and summer months while meiofauna univariate measures were significantly higher during autumn and winter. A complex array of variables may influence the relative significance of the two size benthic groups. Differences in their life strategies, competition for food sources, predatory pressure and disturbances may have different importance. However, if the behavior of each component of the benthos and the interactions between them are 

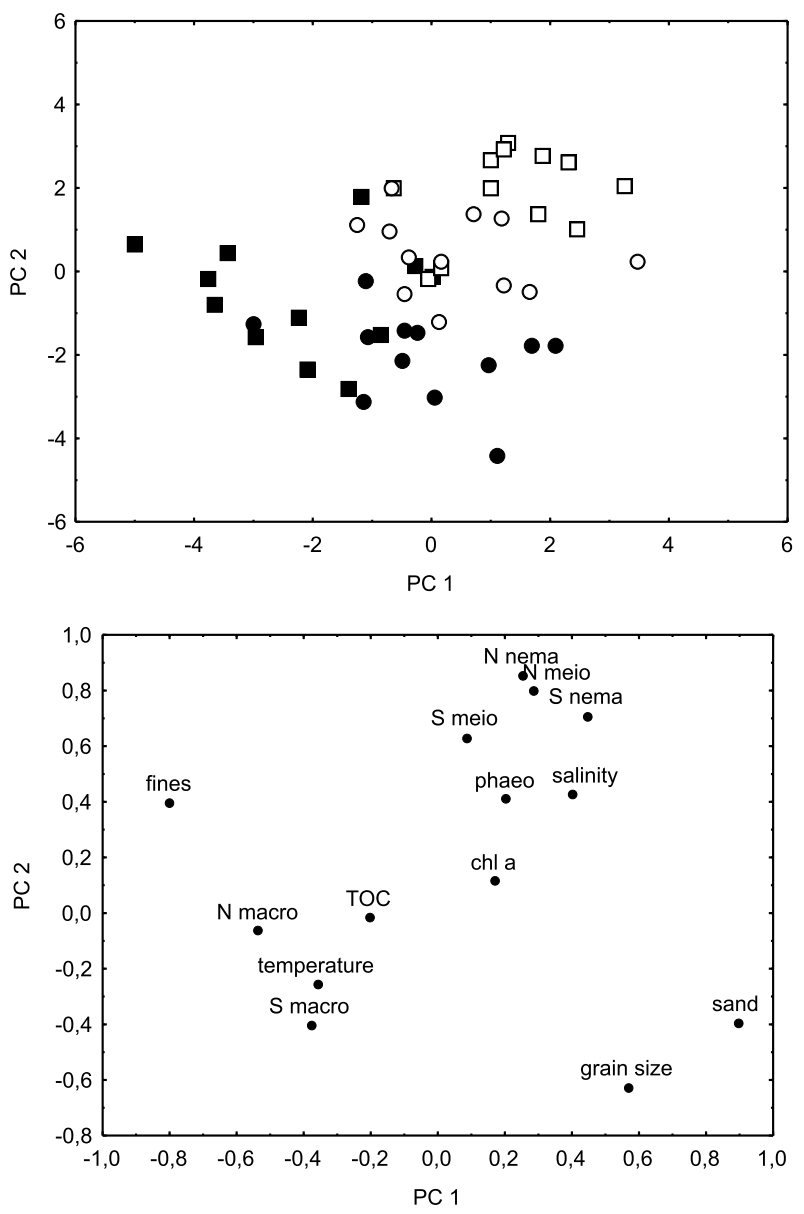

Figure 7 - Ordination of sampling seasons by a correlation-based principal component analysis of environmental variables and univariate measures derived from macrofauna, meiofauna and nematode data $(A)$ and projection of the variables on components 1 and 2 (B). - summer; $\bullet$ - spring; $\square$ - winter ; O - autumn; S mac -number of macrofauna species; $\mathrm{N}$ mac -macrofauna density; $\mathrm{S}$ meio - number of meiofauna higher taxa; $\mathrm{N}$ meio - meiofauna density; S nema - nematode number of genera; $\mathrm{N}$ nema - nematode density; TOC - total organic content; $\mathrm{Chl} \mathrm{a} \mathrm{-} \mathrm{sediment} \mathrm{chlorophyll}$ a biomass ; phaeo - sediment phaeopigments biomass.

to be understood, simultaneous observations on the different components of the benthic community should be make.

\section{ACKNOWLEDGMENTS}

This study was conducted within the project Use and Appropriation of Coastal Zone Resources, Millennium Institute, and was supported by CNPq/PADCT (Brazilian Research Council/Scientific and Technological Development Support Program). We thank Isra Valgas, Gustavo Fonseca, Fabi Gallucci and Tiago Pereira for sampling assistance. CENTEC/UNISUL is thanked for the analysis of sediment. We also thank two anonymous referees for their contribution in improving the manuscript.

\section{REFERENCES}

Admiraal, W. \& Peletier H. 1980. Influence of seasonal variations of temperature and light on the growth rate of cultures and natural populations of intertidal diatoms. Mar. Ecol. Progr. Ser. 2: 35-43.

Alongi, D.M. \& Tenore, K.R. 1985. Effect of detritus supply on trophic relationships within experimental benthic food webs: I. Meiofauna-polychaete (Capitella capitata (typel) Fabricius) interactions. J. Exp. Mar. Biol. Ecol. 88: 153-166.

Attrill, M.J. \& Rundle, S.D. 2002. Ecotone or ecocline: ecological boundaries in estuaries. Est. Coast. Shelf Sci. 55: 929-936.

Austen, M.C. \& Widdicombe, S. 2006. Comparison of the response of meio- and macrobenthos to disturbance and organic enrichment. J. Exp. Mar. Biol. Ecol. 330: 96-104.

Bemvenuti, C.E. \& Netto, S.A. 1998. Distribution and seasonal patterns of the sublittoral benthic macrofauna of Patos Lagoon (South Brazil). Rev. Bras. Biol. 58:211-221.

Blaber, S.J.M.; Cyrus ,D.P.; Albaret, J.J.; Ching, C.V.; Day, J. W.; Elliott, M.; Fonseca, M. S.; Hoss, D. E.; Orensanz, J.; Potter, I. C. \& Silvert, W. 2000. Effects of fishing on the structure and functioning of estuarine and nearshore ecosystems. ICES J. Mar. Sci. 57: 590-602.

Bolam, S.G.; Schratzberger, M. \& Whomersley, P. 2006. Macro- and meiofaunal recolonization of dredged material used for habitat enhancement: temporal patterns in community development. Mar. Poll. Bull. 52: 1746-1755.

Buffan-Dubau, E. \& Carman, K.R. 2000. Diel feeding behavior of meiofauna and their relationships with microalgal resources. Limnol. Oceanogr. 45: 381395.

Clarke, K.R. \& Green, R.H. 1988. Statistical design and analysis for a 'biological effects' study. Mar. Ecol. Prog. Ser. 46: 213-226.

Coull, B.C. \& Chandler, G.T. 1992. Pollution and meiofauna: field, laboratory and mesocosm studies. Oceanogr. Mar. Biol. Ann. Rev. 30: 191-271.

Danovaro, R.; Fraschetti, S.; Belgrano, A.; Vincx, M.; Curini-Galletti, M.; Allbertelli, G. \& Fabiano M. 1995. The potential impact of meiofauna on the recruitment of macrobenthos in subtidal coastal benthic community of the Ligurian Sea (Northwestern Mediterranean): a field result. XXVIII E.M.B.S.,Hersonissos, Creta, 115-122 pp. 
Defant, A. 1961. Physical Oceanography, vol I. Pergamon Press, Oxford, 729 p.

Eichler, P.P.B; Castelão, G.P.; Pimenta, F.M. \& Eichler, B.B. 2006. Avaliação da saúde ecológica do Sistema Estuarino de Laguna (SC) baseado nas espécies de foraminíferos e tecamebas. Pesq. Geocien. 33: 101-115.

EPAGRI. 2006. Empresa de Pesquisa Agronômica e Extensão Rural de Santa Catarina - Centro Integrado de Meteorologia e Recursos Hídricos de Santa Catarina. http://www.epagri.rct-sc.br/.

Fonseca, G. \& Netto, S.A. 2006. Shallow sublittoral benthic communities of the Laguna Estuarine System, South Brazil. Braz. J. Oceanogr, 54: 4154.

Gallucci, F. \& Netto, S.A. 2004. Effects of the passage of cold fronts over a coastal site: an ecosystem approach. Mar. Ecol. Prog. Ser. 281: 79-92.

Gee, J.M. 1989. An ecological and economic review of meiofauna as food for fish. Zool. J. Linnean Soc. 96: 243-261.

Grant, J.; Bathmann, U.V. \& Mills, E. L. 1986. The interaction between benthic diatom films and sediment transport. Estuar. Coast. Shelf Sci. 23: 225-238.

Hall, S.J. 1994. Physical disturbance and marine benthic communities: life in unconsolidated sediments. Oceanogr. Mar. Biol. Ann. Rev. 32: 179-239.

Kettler, T.A.; Doran, J.W. \& Gilbert, T.L. 2001. Simplified method for soil particle-size determination to accompany soil-quality analyses. Soils Sci. Soc. Am. J. 65:849-852.

Kjerfve, B. 1988. Hydrodynamics of estuaries. CRC Press, Boca Raton, $577 \mathrm{p}$.

Koop, K. \& Griffiths, C. L. 1982. The relative significance of bacteria, meio- and macrofauna on an exposed sandy beach. Mar. Biol. 66: 295-300.

Lana, P.C. 1986. Macrofauna bêntica de fundos sublitorais não consolidados da Baía de Paranaguá (Paraná). Nerítica 1:79-89.

Lana P.C.; Couto E.C.G. \& Oliveira M.V.O. 1997. Polychaete distribution and abundance in intertidal flats of Paranaguá Bay (Brazil). Bull. Mar. Sc. 60(2): 433-442.

Lorenzen, C.J. 1967. Determination of chlorophyll and phaeopigments: spectrometric equations. Limnol. Oceanogr. 12: 343-346.

Maclntyre, H. L.; Geider, R. J. \& Miller, D. C. 1996. Microphytobenthos: the ecological role of the "secret garden" of unvegetated, shallow-water marine habitats. I. Distribution, abundance and primary production. Estuaries 19: 186-201.

Moens, T. \& Vincx, M. 1996. Do meiofauna consume primary production?: about many questions and how to answer them. In: Baeyens, J. (ed.) Integrated
Marine System Analysis. European Network for Integrated Marine System Analysis, FWO Vlaanderen: minutes of the first network meeting, Brugge, 188- $202 \mathrm{pp}$.

Montagna, P.A. \& Kalke, R.D. 1992. The effects of freshwater inflow on meiofaunal and macrofaunal populations in the Guadalupe and Nueces Estuaries, Texas. Estuaries 15(3): 307-326.

Morrisey, D.J.; Howitt, L.; Underwood, A.J. \& Stark, J.S. 1992. Spatial variation in soft sediment benthos. Mar. Ecol. Prog. Ser. 81: 197-204.

Nichols, M.M. \& Boon, J.D. 1994. Sediment transport processes in coastal lagoons. In Kjerfve, B. (ed) Coastal lagoon processes. Elsevier, New York, pp. 157-219.

Ólafsson, E. 2003. Do macrofauna structure meiofauna assemblages in marine soft-bottoms? A review of experimental studies. Vie Milieu 53: 249-265.

Pinckney, J. \& Zingmark, R.G. 1993. Biomass and production of benthic microalgal communities in estuarine habitats. Estuaries, 16 (4): 667-897.

Rizzo, W.M.; Lackey, G.L. \& Christian, R.R. 1992. Significance of euphotic, subtidal sediments to oxygen and nutrient cycling in a temperate estuary. Mar. Ecol. Prog. Ser. 86: 51-61.

Rosa, L.C. \& Bemvenuti, C.E. 2006. Temporal variability of the estuarine macrofauna of the Patos Lagoon, Brazil. Rev. Biol. Mar. Oceangr. 41: 1-9.

Shideler, G.L. 1984. Suspended sediment responses in a wind-dominated estuary of the Texas gulf coast. J. Sed. Petrol. 54: 731-745.

Sokal, R. R. \& Rohlf, F. J. 1997. Biometry: the principles and practice of statistics in biological research. Freeman, New York, $887 \mathrm{p}$.

Somerfield, P. J. \& Warwick, R. M.1996. Meiofauna in marine pollution programmes. A laboratory manual. MAFF, Directorate of Fisheries Research, Lowestoft, $45 \mathrm{p}$.

Strickland, J.H.D. \& Parsons, T.R. 1972. A practical handbook of seawater analysis (2nd ed). Fisheries Research Board of Canada, Ottawa, $319 \mathrm{p}$.

Sullivan, M. \& Moncreiff, C. 1990. Edaphic algae are an important component of salt marsh food-webs: Evidence from multiple stable isotope analyses. Mar. Ecol. Progr. Ser. 62: 149-159.

Sundbaeckm, K.; Milesm, A. \& Goeransson, E. 2000. Nitrogen fluxes, denitrification and the role of microphytobenthos in microtidal shallow-water sediments: an annual study. Mar. Ecol. Progr. Ser. 200: 59-76.

Thrush, S.F. \& Dayton, P.K. 2002. Disturbance to marine benthic habitats by trawling and dredging: implications for marine biodiversity. Ann. Rev. Ecol. Syst. 33: 449-473. 
Tita, G.; Desrosiers, G.; Vincx, M. \& Nozais, C. 2000.Predation and sediment disturbance effects of the intertidal polychaetes Nereis virens (Sars) on associated meiofaunal assemblages. J. Exp. Mar. Biol. Ecol. 243: 261-282.

Underwood, A.J. 1997. Experiments in ecology: their logic designs and interpretation using analysis of variance. Cambridge University Press, Cambridge, $504 \mathrm{p}$

Warwick, R.M. 1984. Species size distributions in marine benthic communities. Oecologia, 61: 3241.
Warwick, R.M. 1989. The role of meiofauna in the marine ecosystem: evolutionary considerations. Zool. J. Linn. Soc. 96: 229-241.

Warwick, R.M.; Dashfield, S.L. \& Somerfield, P.J. 2006. The integral structure of a benthic infaunal assemblage. J. Exp. Mar. Biol. Ecol. 330: 12-18.

Warwick, R.M.; Goss-Custard, J.D.; Kirby, R.; George, C.L.; Pope, N.D. \& Rowden, A.A. 1991. Static and dynamic environmental factors determining the community structure of estuarine macrobenthos in SW Britain: why is the Severn estuary different? J. Appl. Ecol. 28: 329-345. 